\title{
MODIFICATION OF CEMENTITIOUS MATRIX OF RAPID-HARDENING HIGH-PERFORMANCE CONCRETES
}

\author{
Lviv Polytechnic National University, \\ Department of Building Production, \\ iryna.i.kirakevych@lpnu.ua
}

(C) Kirakevych I., Sanytsky M., Shyiko O. and Kagarlitskiy R., 2021

The paper presents the results of research concerning the peculiarities of modern High Performance Concretes based on cementitious systems "Portland cement - active mineral additives - microfillers superplasticizers - accelerators of hardening”. Physico-chemical regularities of structure formation of superplasticized cementitious systems are established. It is shown that the formation of secondary fine etringite due to the interaction of active alumina with calcium hydroxide and gypsum in the non-clinker part of the binder because of the effect of "self-reinforcement" compensates for shrinkage and increases the strength of the cementitious system. The modification of the cementitious matrix makes it possible to obtain Rapid Hardening High Performance Concretes that provide early loading and turnover of the formwork of monolithic constructions.

Key words: polycarboxylate, fly ash, limestone powder, metakaolin, superplasticized selfreinforced cementitious systems, Rapid-Hardening High Performance Concretes.

\section{Introduction}

In modern innovative construction the use of High-Performance Concretes (HPC) is constantly expanding, meeting a set of special interrelated requirements for composition, technology and properties, which are not always achieved with traditional approaches. Modern High-Performance Concretes of new generation are associated with their high manufacturability, increased strength and durability. Thus, the forecasted service life exceeds 100 years. At the same time high manufacturability of concrete mixes provides concreting of designs of difficult geometrical forms, including densely reinforced structures, which provides maximum avoidance of labor-intensive, energy-intensive operations of their insertion and compaction, as well as ensuring high quality of the surface of the structure after stripping. At the same time, the complexity of designing High-Performance Concrete is to ensure both high technological properties of concrete mixtures and the required performance characteristics of hardened concrete based on them (Giergiczny, Małolepszy, Szwabowski, \& Sliwinski, 2002). The priority requirement is improved rheological parameters of the concrete mixture - workability, viscosity, segregation, leveling in densely reinforced structures, removal of trapped air. This causes the multicomponent compositions of High-Performance Concrete with using chemical and mineral additives, microfillers, polyfraction aggregates (Proske, Hainer, Rezvani, \& Graubner, 2013).

The main load in the formation of the properties of construction materials of the new generation provides the cementitious matrix, which is formed due to the condensation processes of mineral dispersed systems of different chemical nature (Shi, Qu, \& Provis, 2019). Identification of new characteristics of the components of such systems at the level of nano- and microstructure, as well as the behavior of the system at the level of coagulation phenomena allows to harden the cementitious matrix of building composites taking into account modifications to improve their properties (Esmaeilkhanian, Khayat, \& Wallevik, 2017). Obtaining a dense structure of High-Performance Concrete at the micro level is 
achieved by the following effects: high packing density of grains of the cementitious system (physical optimization); pozzolanic reaction when using active mineral additives (chemical optimization); by increasing the adhesion between the cementitious matrix and the aggregate (optimization of the mesostructure of concrete) (Jaciczak, Wdowska, \& Rudnicki, 2008).

The prospects of using High-Performance Concretes is determined by their main advantage increasing the load-bearing capacity of building construction (columns, supports, load-bearing elements of buildings and structures, etc.). However, the specifics of the compositions of such High-Performance Concrete determines certain features of the construction and technical characteristics of the hardened composite. Thus, according to (Scrivener, \& Nonat, 2011) due to changes in the macrostructure of concrete (the amount of cement paste increases and the coarse aggregate decreases) the shrinkage deformation of High-Performance Concrete increases slightly, and the initial module of elasticity decreases compared to concrete of the same class (Urban, 2018). The feature of high-strength concretes is their low impact strength, increasing sensitivity to cracking and fragility, which appears in the reduction of plastic deformations in concrete under load (Sanytsky, Kropyvnytska, Kirakevych, \& Rusyn, 2013). As a result, high-strength concrete at ultimate loads collapses almost instantly, which poses a threat to the safe operation and reliability of buildings and structures in excess of the design loads in the compressed elements.

Counteracting the destruction and ensuring the effective operation of building structural materials during operation is determined not only by their increased strength, but also by low fragility - the ability of their structure to prevent the formation, growth and spread of cracks At the present stage of development of the science of concrete due to the controlled structure creates the possibility of developing a material with the necessary properties based on the disclosure of relationships in the system "composition - structure - properties of the material" (Kurdowski, 2014). Therefore, the problem of obtaining Rapid-Hardening High-Performance Concrete with improved performance properties is solved by multi-level modification of its structure with additives of different functional purposes in combination with mineral components (Stark, \& Möser, 2002). At the microscale level (cementitious matrix), the reinforcing elements are highly dispersed mineral additives (Soltan, \& $\mathrm{Li}, 2018$ ). At the level of the cementitious matrix effective is the reinforcement by needle-fiber crystals of ettringite, which are formed directly during the hydration of cement, resulting in the phenomenon of "self-reinforcement" at the nanostructural level (Sanytsky, Kropyvnytska, Rusyn, \& Geviuk, 2014).

The use of a complex mineral additive based on metakaolin is of considerable practical interest for the synthesis of ettringite in the cementitious matrix of High-Performance Concrete (Kirakevych, Marushchak, Kirichenko, \& Sanytsky, 2011).

\section{Aim of this article}

The aim of this article is to study the influence of modifiers on the structure of the cementitious matrix for the development of self-reinforced superplasticized cementitious systems "Portland cement clinker - gypsum - active mineral additives - microfillers - superplasticizer - alkali metal salts", which allows to control the hardening of concrete, as well as to optimize the composition of High-Performance Concrete according to the criteria of workability and strength.

\section{Techniques used}

Portland cement CEM I 42.5 R of PJSC "Ivano-Frankivskcement" was used for preparation of High-Performance Concretes. Self-reinforced superplasticized cementitious systems containing fly ash (FA), limestone powder (LP), polycarboxylate-type superplasticizer (PC) and hardening accelerators were developed. The dispersed reinforcement of the cementitious system at the micro level was performed by organo-mineral additives, which include a complex sulfate-aluminate additive (CSAA) based on highly active metakaolin and gypsum. 
High-Performance Concrete was obtain with the use Zhovkva's sand $\left(\mathrm{M}_{\mathrm{f}}=1.8\right)$, and gravel of the 5-20 mm fraction. Alkali metal salts (sodium thiosulfate, etc.) were used as hardening accelerators. The study of the peculiarities of hydration processes of reinforced superplasticized cementitious systems was performed using X-ray phase analysis (DRON-4.0 diffractometer) and scanning electron microscopy (SEM $106 \mathrm{I}$ with a microprobe $\mathrm{X}$-ray spectrum analyzer).

The cementitious system "Portland cement CEM I 42.5 R- complex sulfate-aluminate additive fly-ash - limestone microfiller - polycarboxylate type of superplasticizer - accelerators of hardening" is characterized by the consistency on flow table F=180 mm (DSTU B V.2.7-187:2009) and it can be attributed to superplasticized, which makes it possible to obtain high flowability mixtures and HighPerformance Concrete based on them. During testing the cementitious system according to DSTU B V.2.7-187: 2009 in conditions of increased workability, an increase of 1.4 times the early strength and an increase in compressive strength after 28 days of hardening by $12 \%$. At the same time, due to the significant water-reducing effect $(\Delta \mathrm{W} / \mathrm{C}=23.1 \%, \mathrm{~F}=110 \mathrm{~mm})$ high early strength is achieved (compressive strength $\mathrm{Rc}_{2} / \mathrm{Rc}_{28}=0,69$ ), which corresponds to the standard strength of CEM I $42.5 \mathrm{R}$. The strenght of the cementitious system is $\mathrm{Rc}_{28}=72.5 \mathrm{MPa}$, which determines the technical effect and creates the possibility of obtaining a Rapid-Hardening High-Strength binder. The flexural strength of the cementitious system at an early age in conditions of increased workability increases by $30-32 \%$, and after 28 days - by $10 \%$ compared with the CEM I $42.5 \mathrm{R}$.

In relation to the values of flexural strength to the compressive strength of the self-reinforced superplasticized cementitious system, the brittleness coefficients in different periods of hardening was calculated. It should be noted that in the period of 7-28 days the increase in flexural strength is slower compared to the compressive strength, so the brittleness coefficients of cementitious systems decrease slightly with the curing time. At the same time, after 28 days of curing, their values exceed 0.125 , which allows to classify these cementitious systems as non-brittle. Thus, in the early period of hardening for CEM I $42.5 \mathrm{R}$ the values of brittleness coefficients are reduced by $10-14 \%$, while the change of brittleness coefficients of self-reinforced cementitious systems is more smooth, and their reduction is 2-7\%. This indicates that the use of a complex sulfate-aluminate mineral additive and alkali metal salts in superplasticized cementitious systems provides an accelerated increase in compressive strength due to the "microfiller effect" and paste compaction due to the formation of additional hydrated phases in the non-clinker part and the increase in flexural strength is achieved due to the effect of self-reinforcement of crystal hydrates of ettringite, which are characterized by needle form of habit. Ultimately, this leads to an increase in the brittleness coefficient of the cementitious system compared to the CEM I 42.5 R.

To study the features of hydration processes in the non-clinker part of the cementitious system, the phase composition and microstructure of the model system "CaO : CSAA" (W/S=1) were studied. According to X-ray phase analysis (Fig. 1, a) after 7 days of curing under normal conditions on the diffraction patterns of samples of the studied system there are lines of hydration products - ettringite $(d / n=0.973$; $0.561 \mathrm{~nm}$, etc.), hexagonal calcium hydroaluminates type $\mathrm{C}_{4} \mathrm{AH}_{13}(\mathrm{~d} / \mathrm{n}=0.810,0.395 \mathrm{~nm}$, etc.), which indicates the active phase-forming role of metakaolin in the system with calcium hydroxide and sulfate. After 28 days, the intensity of $\mathrm{Ca}(\mathrm{OH})_{2}$ lines decreases due to its binding by the active mineral components of CSAA, while the lines of ettringite increase. With the curing time (after 180 days) on the diffractograms of the model system there is an increase in the intensity of ettringite lines, which in these model systems is formed without participation of the clinker mineral $3 \mathrm{CaO} \cdot \mathrm{Al}_{2} \mathrm{O}_{3}$ due to the interaction of active $\mathrm{Al}_{2} \mathrm{O}_{3}$ metakaolin with calcium hydroxide and sulfate.

The microstructure of the studied system at an early age is characterized by significant heterogeneity with the presence of lamellar crystals of calcium hydroxide and a small amount of hexagonal calcium hydroaluminates (Fig. 1, $b$ ). After 28 days of curing, the number of gel-like phases increases, with the formation of fine-grained fibrous crystals of ettringite. With further hardening to 180 days, the amount of portlandite decreases, but the number of needle crystals of ettringite increases, which play a reinforcing role and contribute to the compaction of the intergranular space of artificial stone. The 
main characteristic lines of $\mathrm{Ca}, \mathrm{Si}, \mathrm{Al}, \mathrm{S}, \mathrm{O}$ are observed on the X-ray spectrum of hydration products of the model system (Fig. 1,c), which confirms the formation of hydrosilicates, calcium hydroaluminates and ettringite in this model system (Sanytsky, Kropyvnytska, Rusyn, \& Geviuk, 2014).

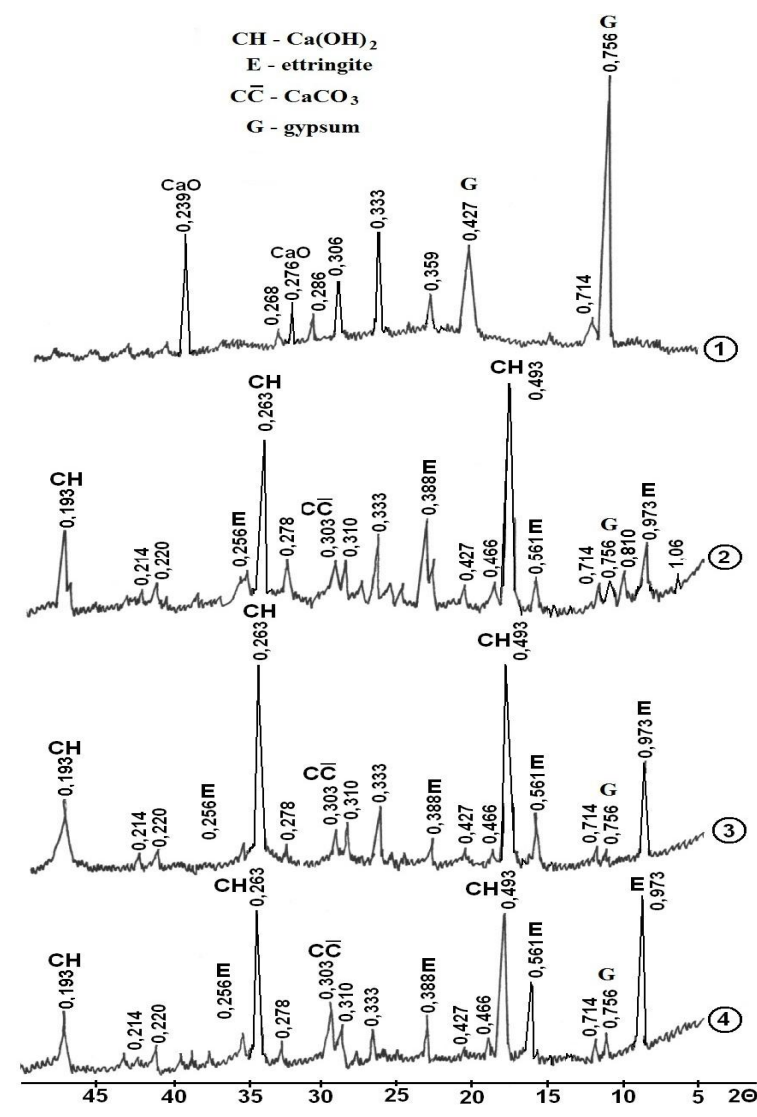

$a$

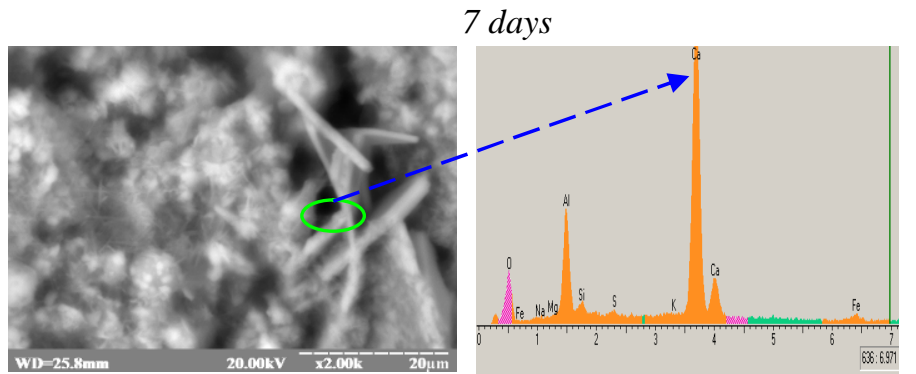

28 days

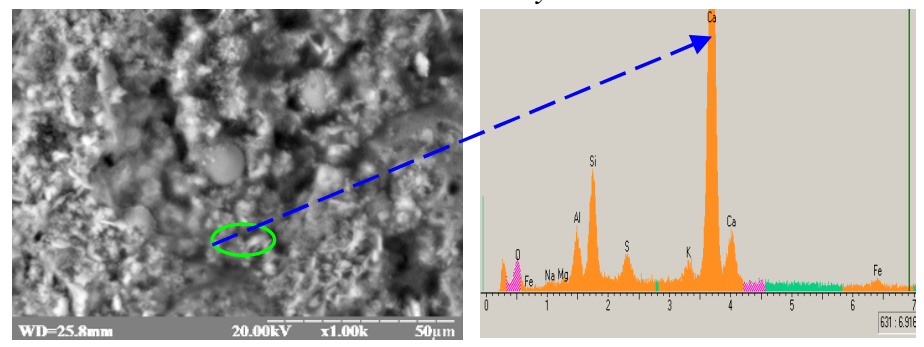

180 days

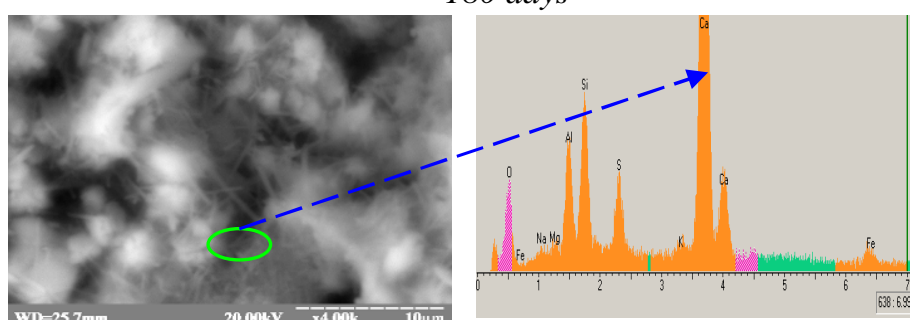

$b$

$c$

Fig. 1. Diffractograms (a), microstructure (b) and X-ray spectrum (c)

of paste on the basis of the model system "CaO :CSAA =1:1":

1 - non-hydrated; 2-4 - hydrated in normal conditions after 7, 28 and 180 days respectively

Analysis of microstructure formation shows that the use of self-reinforced cementitious systems accelerates hydration processes, compaction of the non-clinker part of the cement matrix due to the formation of needle ettringite crystals and colmatation of pores with hexagonal crystals of portlandite, calcium hydroaluminates and hydrocarboaluminates. This causes a redistribution of porosity and increased strength and crack resistance of the cementitious matrix. For highly plastic paste based on CEM I $42.5 \mathrm{R}$, the spread of the Suttard cylinder $\mathrm{F}=400 \mathrm{~mm}$ is achieved at $\mathrm{W} / \mathrm{C}=0.60$, while the total porosity of the paste is $36.5 \%$ (open $-14.7 \%$, closed $-21.8 \%$ ). At the same time, similar workability of the selfreinforced superplasticized rapid-hardening cementitious system is reached at $\mathrm{W} / \mathrm{C}=0.30$, thus porosity of a paste decreases to $26.7 \%$, and the ratio between open and closed porosity changes to 4.3 and $22.4 \%$ accordingly.

Fine mineral additives, such us fly-ash (FA) and limestone powder (LP) accelerate the increasing of strength and compaction of cementitious matrix due to the effect of "fine powders" and plays active structure formation role due to the creating of hydrate phase. These hydrate phases, in particular hydrosilicates of type $\mathrm{CSH}(\mathrm{B})$, structure active $\mathrm{AF}_{\mathrm{m}}$-phases - calcium hydrocarbonates and $\mathrm{AF}_{\mathrm{t}}$-phases ettringite, are characterized by binder properties in unclinker part of composition. Strength of concrete (nominal composition $\mathrm{C}: \mathrm{S}: \mathrm{G}=1: 1.52: 2.04 ; \mathrm{C}=480 \mathrm{~kg} / \mathrm{m}^{3}$ ) with complex sulfate-aluminate additive (CSAA) after 2; 7 and 28 days of hardening is respectively 58.8; 66.5 and $67.9 \mathrm{MPa}$ (Fig. 2) and with the 
addition of limestone powder (LP) $-76.3 ; 80.2 ; 88.2 \mathrm{MPa}$, that allows to attribute these concretes to Rapid-Hardening High-Performance Concretes.

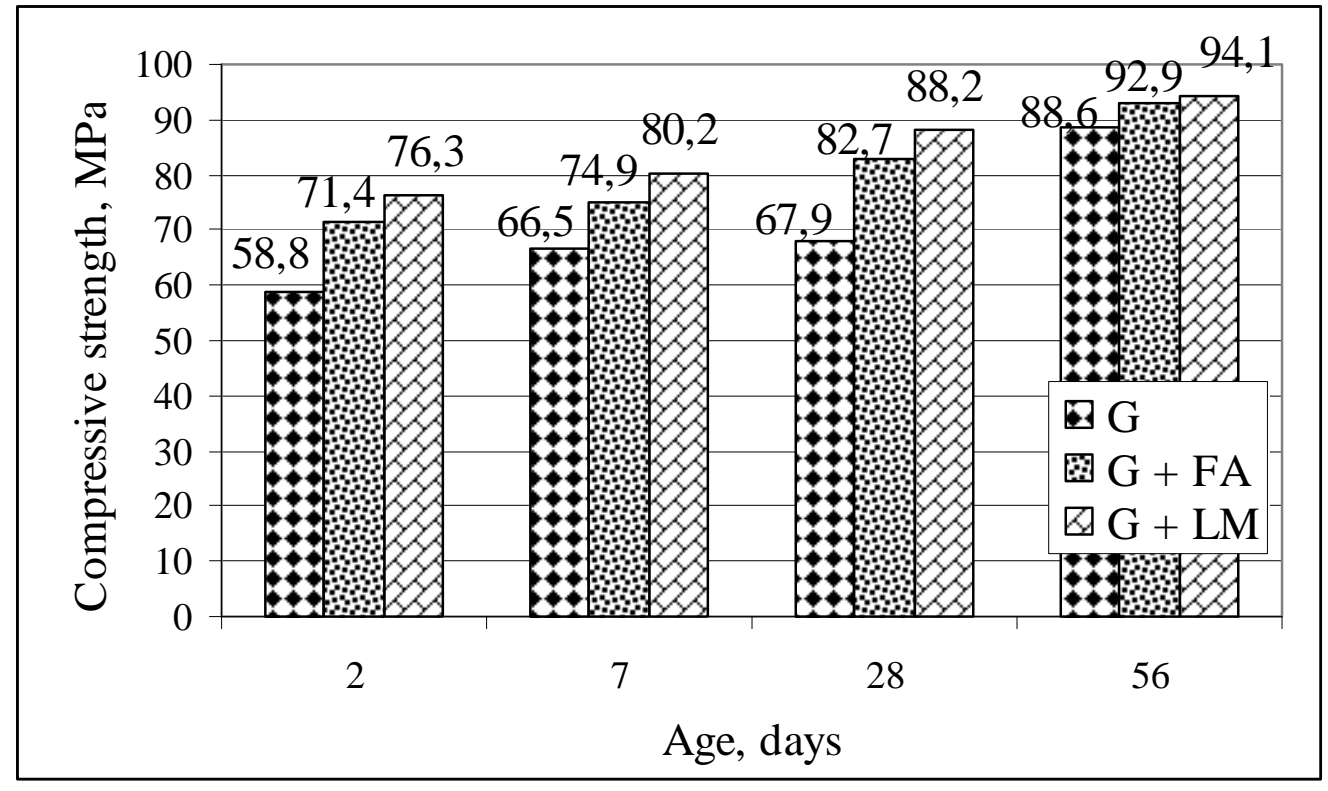

Fig. 2. Compressive strength of High Performance concretes based on superplasticized cementitious systems

\section{Conclusions}

Modification of the structure at the micro level (level of cementing matrix) to implement the effect of "self-reinforcement" due to the formation of secondary fine ettringite in the interaction of active alumina with calcium hydroxide and gypsum in the non-clinker part of the binder, as well as macro level optimization (concrete mesostructure) is an effective way of obtaining Rapid-Hardening High-Performance Concretes based on superplasticized cementitious systems with wide functionality for use in conditions requiring increased crack resistance, compressive and flexural strength. This creates an opportunity for early loading of building structures, which allows to systematically solve the problem of increasing the turnover of the formwork and accelerate the erection of monolithic structures.

\section{References}

Giergiczny, Z., Małolepszy, J., Szwabowski, J., \& Sliwinski, J. (2002). Cementy z dodatkami mineralnymi w technologii betonow nowej generacji. Gorazdze cement. Opole, 191. Corpus ID: 221300430. Retrieved from: https://www.semanticscholar.org/

Proske, T., Hainer, S, Rezvani, M., \& Graubner, C.-A. (2013). Eco-friendly concretes with reduced water and cement contents. Mix design principles and laboratory tests. Cement and Concrete Research, 51, 38-46. Retrieved from: https://www.sciencedirect.com/science/article/abs/pii/S000888461300094X.

Shi, G., Bo, Q., \& Provis, J. (2019). Recent progress in low-carbon binders. Cement and Concrete Research, 122, 227-250. Retrieved from: https://www.sciencedirect.com/science/article/abs/pii/S0008884619301838.

Esmaeilkhanian, B., Khayat, K., \& Wallevik O. (2017). Mix design approach for low-powder selfconsolidating concrete: Eco-SCC - content optimization and performance. Materials and Structures. Retrieved from: https://link.springer.com/article/10.1617/s11527-017-0993-y.

Jasiczak, J., Wdowska, A., \& Rudnicki, T. (2008). Ultra-High Performance Concretes. Properties, Technology, Applications. Kraków, 157. Retrieved from: https://www.researchgate.net/publication/342720481.

Scrivener, K., \& Nonat, A. (2011). Hydration of cementitious materials, present and future. Cement and Concrete Research, 41:7, 651-665. doi: 10.1016/j.cemconres.2011.03.026. 
Urban, M. (2018). Low cement content SCC (Eco-SCC) - the alternative for ready-mix traditional concrete. MATEC Web of Conferences, 163, 01004. doi: 10.1051/matecconf/201816301004.

Sanytsky, M., Kropyvnytska, T., Kirakevych, I., \& Rusyn, B. (2013). Structure formation and strength of modified multimodal composite cements. Odessa State Academy of Civil Engineering and Architecture, 52, 230-236. Retrieved from: http://nbuv.gov.ua/UJRN/Vodaba_2013_52_36.

Kurdowski, W. (2014). Cement and Concrete Chemistry. Springer Dordrecht, Netherlands. doi: 10.1007/97894-007-7945-7.

Stark, J., \& Möser, B. (2002). Nano and microstructure of Portland cement paste. International workshop, 15-25. Essen, Germany.

Soltan, D., \& Li, V. (2018). A self-reinforced cementitious composite for building-scale 3D printing. Cement and Concrete Composites. doi: 10.1016/j.cemconcomp.2018.03.017.

Sanytsky, M., Kropyvnytska, T., Rusyn, B., \& Geviuk, I. (2014). Multimodal composite Portland cements, modified with ultrafine mineral additives. Theory and Building Practice, 781, 158-161. Retrieved from: http://nbuv.gov.ua/UJRN/VNULPTPB_2014_781_31.

Kirakevych, I., Marushchak, U., Kirichenko, I., \& Sanytsky M. (2011). Structure formation and properties of rapid-hardening Self-compacting concrete, 80-85. Budownictwo o zoptymalizovanym potenciale energetycznym. Praca zbiorova pod. red. T. Bobki, J. Rajczyka. Czestochowa.

І. І. Кіракевич, М. А. Саницький, О. Я. Шийко, Р. Р. Кагарлицький Національний університет “Львівська політехніка", кафедра будівельного виробництва

\section{МОДИФІКУВАННЯ ЦЕМЕНТУЮЧОЇ МАТРИЦІ ШВИДКОТВЕРДНУЧИХ ВИСОКОФУНКЦІОНАЛЬНИХ БЕТОНІВ}

() Кіракевич I. I., Саницький М. А., Шийко О. Я., Кагарлицький Р. Р., 2021

Наведено результати одержання швидкотверднучих високофункціональних бетонів на основі суперпластифікованих самоармованих цементуючих систем, що грунтуються на встановлених закономірностях структуроутворення і модифікування портландцементних композицій “портландцемент - активні мінеральні добавки - мікронаповнювачі - суперпластифікатори - прискорювачі тверднення”.

Комплексом методів фізико-хімічного аналізу досліджено особливості процесів гідратації та тверднення суперпластифікованих самоармованих цементуючих систем. За результатами досліджень процесів структуроутворення суперпластифікованих самоармованих цементуючих систем встановлено, що утворення вторинного дрібнодисперсного етрингіту під час взаємодії активного оксиду алюмінію з кальцію гідроксидом та двоводним гіпсом у неклінкерній частині в'яжучого за рахунок ефекту “самоармування” забезпечує компенсацію усадки та приріст міцності цементуючої системи.

Показано, що використання суперпластифікованих самоармованих цементуючих систем дає змогу впливати на технологічні властивості та кінетику структуроутворення і створювати міцну структуру бетону з покращеними будівельно-технічними властивостями. Застосування раціонально підібраних суперпластифікованих самоармованих цементуючих систем вирішує проблему одержання швидкотверднучих високофункціональних бетонів на основі самоущільнювальних сумішей 3 використанням безвібраційної технології монолітного бетонування. Створюється також можливість раннього навантаження конструкцій, збільшення оборотності опалубки та прискорення зведення монолітних конструкцій.

Ключові слова: полікарбоксилат, зола винесення, вапняковий мікронаповнювач, метакаолін, суперпластифіковані самоармовані цементуючі системи, швидкотверднучі високофункціональні бетони. 